\title{
Modeling of Sediment Behavior on Urban Watershed and Determination of Climate Change Effects
}

\author{
B. Şimşek Uygun and M. Albek
}

\begin{abstract}
Technological advances which accelerated after the industrial revolution, extensive fossil fuel usage, land use changes and emissions of greenhouse gases from various sources contribute to global warming and consequently climate change. Climate change affects hydrological and ecological processes significantly. In this study, effects of impervious areas of Eskişehir, a city in the Porsuk Stream Watershed in Western Inner Anatolia of Turkey, to the Porsuk Stream pollution between 1975 and 2010 have been studied. For the determination of these effects the HSPF model (Hydrological Simulation Program-Fortran) developed by United States Environment Protection Agency-EPA has been used. Since sediment concentration is very important to investigate the modeling, behavior sediment has been modeled. In the impervious land segments, sediment concentration is high and so impervious land segments have been found to be affecting sediment parameter concentrations meaningfully. The parameter values have been set to their extreme values to investigate the resulting effects on the concentrations. It has been determined that the maximum sediment concentration in outflow becomes $570 \mathrm{mg} / \mathrm{L}$ in the Porsuk Stream based on monthly averages respectively. In addition, with using climate scenario A1 simulated until 2100, sediment concentration is increasing significantly. By this way, urban centers effects on watershed hydrology and water quality in response to climate change have been investigated.
\end{abstract}

Index Terms - Climate change, hydrological model, water pollution.

\section{INTRODUCTION}

Water is the most important source of life and it is in some places in limited quantities in nature. Human activities have had negative impact from the first centuries on the environment. This effect was initially a relative one and the environment well tolerated this effect with its natural mechanism, but as a result of human activities, especially after the industrial revolution, greenhouse gases increased which led to climate change. Available water resources are affected by climate change. Heat waves, rainfall, drought, sea level rise, natural disasters occur as a result of climate change. In the event of continued global warming, extreme high temperatures in some areas, overflows, widespread and severe drought events, completely disrupt the ecological balance changes and as a result water resources are expected to be negatively affected.

Environmental pressures that lead to the loss of water resource shave great importance. In this study, the effects of

Manuscript received December 20, 2012; revised February 12, 2013 This work was supported by Scientific and Technological Research Council of Turkey.

The authors are with Anadolu University Environmental Engineering Department, 26555, Turkey (e-mail: bsimsek1@anadolu.edu.tr, mlule@anadolu.edu.tr). climate change on urban watersheds are analyzed using HSPF(Hydrological Simulation Program-Fortran) model program. Predictions are made into the future to see the effects the climate change on water resources creates. In addition it is thought to be a guideline for better management of watershed.

Sediment, which is one of the most important parameters that causes water pollution, has been modeled. Sediment reaches streams from different sources, including natural and artificial sources of sediment collected in two groups of sources; stream channel erosion, landslides, agricultural processes, construction for a variety of purposes, stream channel improvement works and mining. In receiving waters like streams, sediment reduces light transmission by turbidity. Impervious areas increase urban nonpoint source pollution and also degrade in stream habitat and biota [1].

\section{STUDY AREA}

The study area is Eskişehir for analyzing impacts of urban watershed. Eskişehir is the largest city in the Porsuk Stream Watershed which is $58160 \mathrm{~km}^{2}$ in area so it covers $7 \%$ of Turkey's surface area. Generally, the watershed topography is mild.

There have been projects for irrigation, domestic water use and also energy generation in the watershed. Water pollution in the watershed is increasing rapidly because of population increase and also industrialization, so some tributaries of the stream are known to be significantly contaminated [2]. The Porsuk reservoir, which has been built in 1972, aims overflow protection and also irrigation.

The Lower Porsuk Stream Watershed has continental climate due to geographical area, altitude, land forms and distance from the sea. The winters are cold and wet, the summers hot and arid. The average annual mean temperature is $10.6^{\circ} \mathrm{C}$ and the annual precipitation is $347 \mathrm{~mm}$ on the basis of records of the past 34 years.

Urban areas which have high percentage of impervious surface are nonpoint pollution sources. Runoff from impervious surfaces, for example; streets, roofs, asphalt areas, parking lots cause pollution in streams and rivers [3]. Eskişehir's impervious areas are determined to be 14336 acre $\left(58 \mathrm{~km}^{2}\right)$ with using Arc GIS Explorer. It is nearly 50\% of Eskişehir's areas.

\section{HSPF MODEL APPLICATION}

HSPF is a program that simulates almost all quantitative and qualitative processes of the hydrological cycle in a watershed on a continuous basis. Studies on the hydrological component of the model began in 1966 with the Stanford 
Watershed Model. Over the years, the information obtained from field observations have been added to the model.

HSPF simulates pervious and impervious land and water environments. Pervious land segments are modeled with the PERLND module, impervious land segments are simulated with IMPLND module, water bodies like streams, reach and reservoir are modeled by RCHRES module. In this study, IMPLND module which constitutes HSPF has been used. In an impervious land segment, there is little or no infiltration. Snow can accumulate and melt and water can be stored or evaporate. Several water quality constituents accumulate and removed. Water, solids and several pollutants flow from the segments by moving laterally to a down slope segment or to a reservoir.

Parameters needed for the model are taken as standard values from the literature. Common parameters used in the literature or calculated on the basis of the values used in watersheds with similar characteristics are used. The most important parameter values used in the module are shown in the Table I.

TABLE I: PARAMETER VALUES USED IN HSPF

\begin{tabular}{|c|c|c|c|}
\hline & $\begin{array}{l}\text { Impervious } \\
\text { Parameters }\end{array}$ & Value & Units \\
\hline Overland Flow Length & LSUR & 570 & $\mathrm{ft}$ \\
\hline Manning's n For Overland Flow & NSUR & 0.05 & none \\
\hline Temperature Maximum for ET & PETMAX & 4.4 & ${ }^{\circ} \mathrm{C}$ \\
\hline Temperature That ET is Zero & PETMIN & 1.6 & ${ }^{\circ} \mathrm{C}$ \\
\hline $\begin{array}{l}\text { Retention Storage Capacity of the } \\
\text { Surface }\end{array}$ & RETSC & 0.05 & in \\
\hline Slope of Overland Flow Length & SLSUR & 0.04 & none \\
\hline Surface Water Storage & SURS & 0.1 & in \\
\hline $\begin{array}{l}\text { Coefficient for Transport of } \\
\text { Solids }\end{array}$ & KEIM & 1 & none \\
\hline Exponent for Transport of Solids & JEIM & 1.2 & none \\
\hline $\begin{array}{l}\text { Accumulation Rate of Solids } \\
\text { Storage }\end{array}$ & ACCSDP & 0.3 & tons/acre.day \\
\hline Unit Removal of Solids in Storage & REMSDP & 0.05 & / day \\
\hline $\begin{array}{l}\text { Solids Storage at the end of the } \\
\text { Day }\end{array}$ & SLDS & 0.2 & tons/acre \\
\hline
\end{tabular}

HSPF needs meteorological time series. These are temperature, dew point temperature, precipitation, cloudiness, wind speed, solar radiation, potential evaporation and transpiration. The data for the time series have been acquired from State Meteorological Agency of Turkey. The Watershed Data Management (WDM) program was used to supply time series to the model. HSPF connects meteorological time series with other modules of the program and simulates. Daily simulations between 19752010 have been carried out.

SOLIDS part of the sub-moduleis used for the simulation of solid materials in IMPLND module. Solids accumulation rate, the amount of material removed from impervious area on a daily basis given as an input to the program. The amount of removed material is calculated with $\mathrm{R}=\mathrm{P} *(\mathrm{E} / \mathrm{D})$ formula which $\mathrm{R}$ is amount of sediment removed by sweeping streets, $\mathrm{P}$ impervious fraction of area, E cleaning efficiency, D frequency of cleaning and also it is found that 0.05 /day.

\section{RESUlTS AND Discussion}

SOLIDS sub-module has been used to investigate the effects of sediment behavior. The differences between the sediment concentrations with and without SOLIDS sub module have been compared with a t-test. The humaninduced pollution, street, street cleaning, dusts etc. in Eskisehir Porsuk Stream effect of the amount of particulate matter were found to be too much. Impervious land segments have been found to be affecting sediment concentrations significantly with the $t$ test.

Besides, the parameter values have been set to their extreme values to investigate the resulting effects on the concentrations. It has been determined that the maximum sediment concentration in outflow becomes $570 \mathrm{mg} / \mathrm{l}$ and the minimum is $8 \mathrm{mg} / \mathrm{l}$ in Fig. 1.

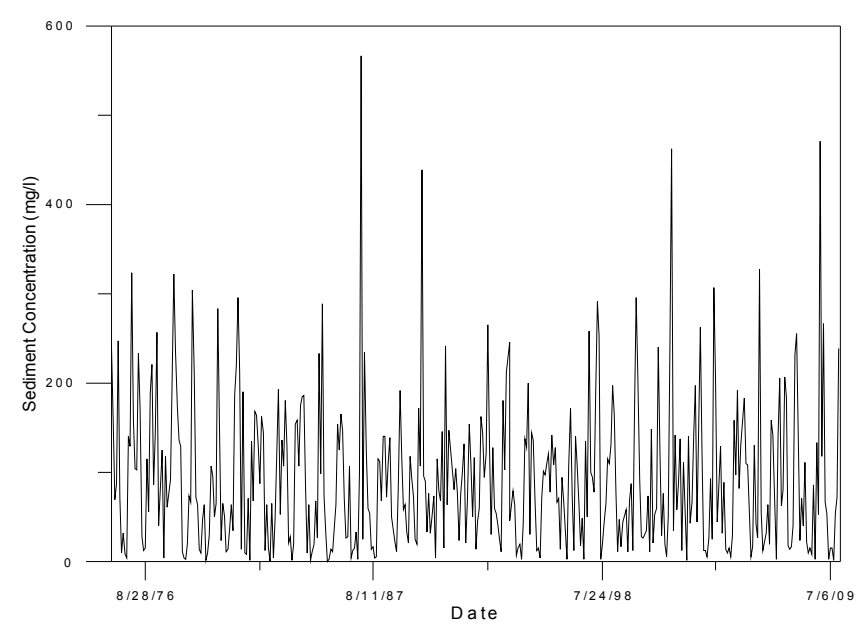

Fig. 1. Sediment concentration in impervious land segment (monthly average).

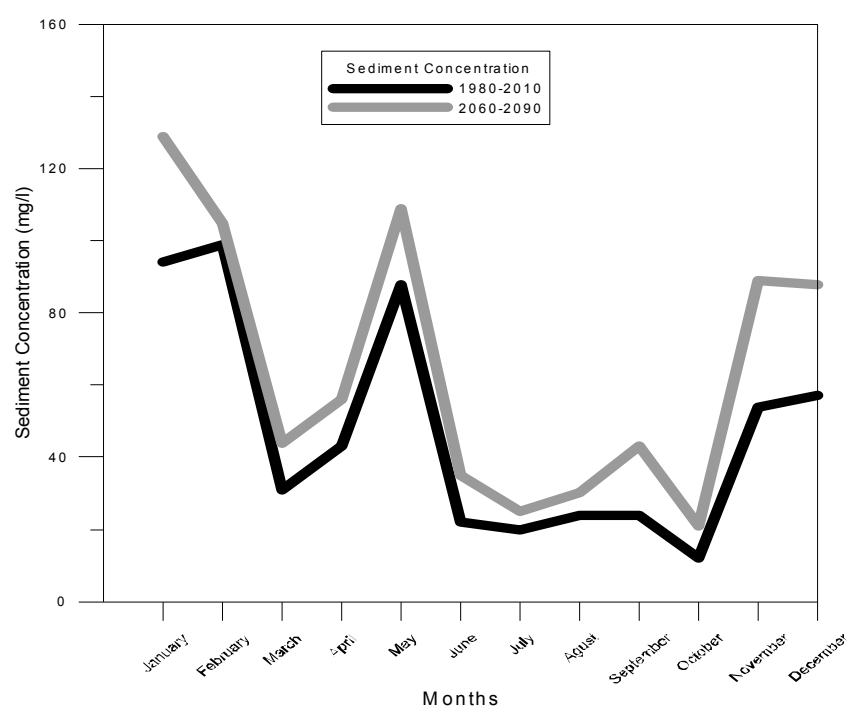

Fig. 2. Climate scenarious of sediment concentration between 1980-2010 and 2060-2090.

In addition, A1 scenario is used which is one of the SRES scenarios. The A1 storyline and scenario family describes a future world of very rapid economic growth, global population that peaks in mid-century and declines thereafter, and the rapid introduction of new and more efficient technologies. Major underlying themes are convergence among regions, capacity building, and increased cultural and social interactions, with a substantial reduction in regional differences in per capita income [4]. By using climate scenario simulated till 2100 , sediment concentrations have 
been seen to increase significantly in Fig. 2.

The sediment concentration with and without SOLIDS sub module is presented in Fig. 3.

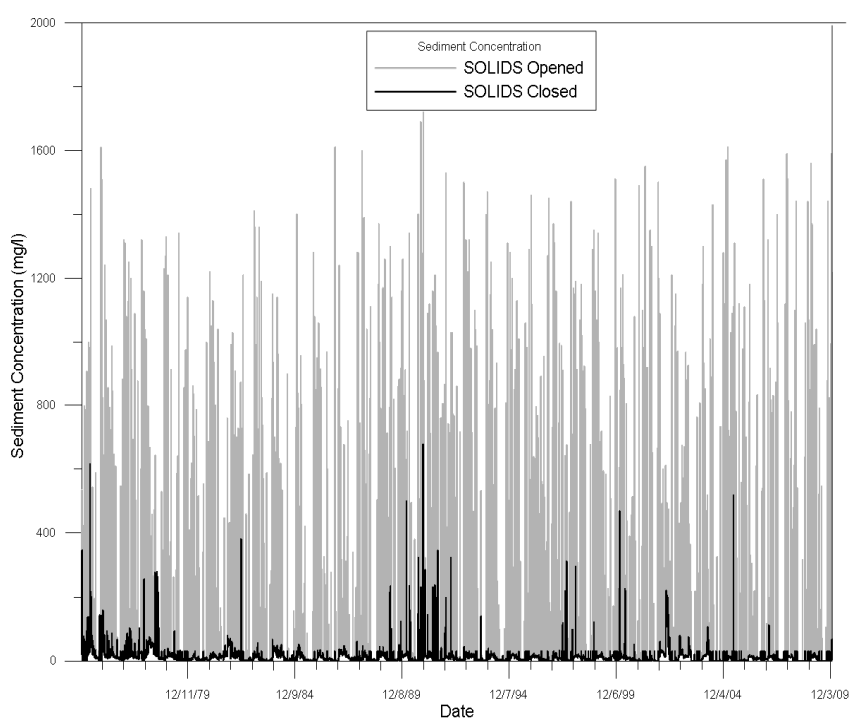

Fig. 3. Module of SOLIDS effects to impervious land segment.

\section{REFERENCES}

[1] V. Novotny, Water Quality Diffuse Pollution and Watershed Management, John Wiley \& Sons, Inc., New York, 2003.

[2] W. Z. Wang and J. Y. Jiao, Rainfall and erosion sediment yield in the Loess Plateau and sediment transportation in the Yellow River basin. Science Press, 1996, pp. 132-134.

[3] D. Weber and R. Bannerman, "Relationships between impervious surfaces within a watershed and measures of reproduction in fathead minnows (Pimephalespromelas)," Hydrobiologia, vol. 525, pp. 215228, 2004.

[4] Climate Change Scenarios: IPCC story lines, models, downscaling. [Online]. Available: http://www.ess.co.at/METEO/CCS.html

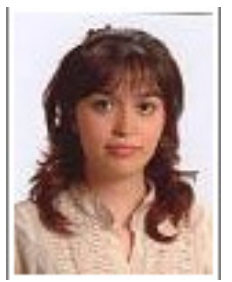

B. Şimşek Uygun was born in Ankara, Turkey in November, 1985. Burcu was graduated from Atatürk High School in 2003, then she was graduated from Anadolu University Environmental Engineering Department in Eskişehir with first degree in 2008. Since then, Burcu is working as a research assistant at Anadolu University. Her master thesis is about climate change, water pollution and also environmental modeling. She studied in a project and she completed master degree in 2011. Ms. Ş. Uygun is now a PhD student at Anadolu University and going on studying these themes. 